透過電顕及び走查電顕によるヒト肝細胞細胞骨格の研究

$\begin{array}{llllllll}\text { 岡上 } & \text { 武* } & \text { 太田 } & \text { 正治* } & \text { 加知 } & \text { 一友* } & \text { 山岸 } & \text { 久一** } \\ \text { 弘中 } & \text { 武** } & \text { 金岡 } & \text { 彦治* } & \text { 澤 } & \text { 美彦* } & \text { 太田 } & \text { 義治* } \\ \text { 王 } & \text { 嗢玉* } & \text { 香川 } & \text { 恵造* } & \text { 奥野 } & \text { 忠雄* } & \text { 瀧野 } & \text { 辰郎* }\end{array}$

要 旨：光顕的に正常肝組織像を呈するヒト肝組織片 6 個を対象とした. 試料採取直後に細切 し, 凍結割断の後に detergent で処理する方法と, 採取した肝組織片に静注針を刺入し deter-

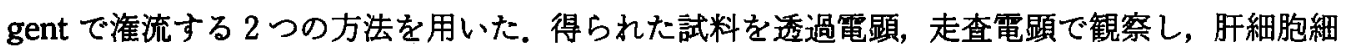
胞骨格(H-CS)の二次元的, 三次元的存在様式を明らかにした. 細胞質全体に亘って中間径フィ ラメント（IFs）が多数存在し, IFs は接着・吻合を示し, 微小管やマイクロフィラメントも観 察できた。肝細胞と肝細胞の間で割断された試料では，毛細胆管周囲や細胞境界部が明瞭で， 多くのCSが存在し、マイクロフィラメントも多数残存していた，今回の研究成績は，今後ヒト の肝細胞細胞骨格病理の研究に有用であると考えた。

索引用語： 肝細胞細胞骨格 中間径フィラメント 走查電顕

はじめに

生体においては，肝細胞はディッセ腔に面した側か ら種々の物質を取り込み，細胞内を移送し，一部は毛 細胆管腔内に排泄する patic transport に肝細胞細胞骨格 (hepatocyte cytoskeleton: H-CS）が重要な役割を果たしていることは 采知の事実である.

肝細胞にはマイクロフィラメント，中間径フィラメ ント（IFs）と敏小管の 3 種の CS が存在しているが， 著者ら 2,31はラットやマウスを対象に, 透過電顕, 走査 電顕を用い, H-CS の二次元的, 三次元的存在様式を検 討してきた，著者らの発表した走査電顕による H-CS の研究法は，肝疾患の細胞骨格病理を研究する上でき わめて価値のある研究法であるとの評価をえてい る゙. 胆汁らっ滞やアルコール性肝障害にみられる肝 の病理形態学的変化の原因としてH-CS の変化が重視 され、ラットやマウスを用いて著者らはこの方面の研 究を続けてきた。しかし，ヒト H-CS の立体構築に関 する報告は未だみられていない，今回，外科手術時に えられた肝組織片を対象に, ヒト H-CS の存在様式に ついて，透過電顕，走查電顕を用いて検討したので報 告する.

\footnotetext{
- 京都府立医科大学第 3 内科

** 京都府立医科大学第 2 外科
}

<受付日61年 7 月21日 $>$

\section{対象と方法}

消化器癌の肝転移例 2 症例の肝部分切除と 4 例の胃 切除時に施行された楔状肝生検の計 6 組織片を対象之 した。揳状肝生検は全例術前に患者の同意をえて施行 した．得られた肝組織の一部を室温で直ちにへパリン 加生理食塩水に浸漬し, 残りは光顕用にホルマリン固 定を行った。電顕による H-CSの観察を目的として, 2 種類の試料作成法を試みた。第 1 法としては，生食 に漫漬したままの肝組織片に21Gの静注針を刺入し， $37^{\circ} \mathrm{C}$ に保温した $0.5 \%$ Triton X-100を含むJahnの液5) を使用し，流量 $5 \mathrm{~m} l /$ 分で60分間潅流した，潅流60分後 には，肝組織の大部分は黄白色となり，その部分を電 頭用試料作成に用いた。透過電顕用には潅流後の肝組 織を $0.1 \%$ テニウムレッド含有の $2 \%$ オスミウム酸 で固定の後， 2 \%酢酸ウラニールでブロック染色し， エタノールで脱水の後エポンに包埋した。

走査電顕用には，潅流した肝組織片を既報2)のごと く2.5\%グルタールアルデヒドで固定の後, 改良タンニ ン酸オスミゥム導電染色を施し，エタノール系列で脱 水した. イソアミール・フセテートで置换の後, 臨界 点乾燥し, 白金パラジゥム $(\mathrm{Pt}-\mathrm{Pd})$ を約 $30 \AA$ の厚さに 蒸着し、日立 S-520LB 型走査電顕で観察した.

第 2 法としては，採取した肝組織片の一部を $1 \times 1 \times$ $5 \mathrm{~mm}$ の大きさに細切し,その組織片を液体窒素で泠却 したインペンタン中でカミンリを用いて割断した。割 
断した組織片を0.5\%Triton X-100を含むJahnの液 ${ }^{5)}$ に30分間浸漬し，その後 $2.5 \%$ ルタールアルデヒドで 固定し，以後は第 1 法に準じて処理した。な挌 6 症例 の肝組織のへマトキシリン・エオジン染色の光顕所見 は全て正常肝組織像であった。

\section{結 果}

透過電顕による観察では, 細胞膜や細胞内小器官の 大部分は破壊, 消失していたが，一部の肝細胞では多 数のリボゾームとともに脂肪滴を散在性に認めた。核 膜もほとんど存在していなかったが，核の同定は容易 であり,多数の CS が核や脂肪滴に付着し, 細胞質内に

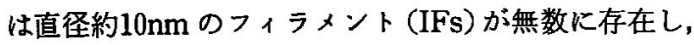
直径約 $27 \mathrm{~nm}$ の微小管も少数察できた（Fig. 1).

次に走査電顕による観察結果を述べる. 第 1 法で処 理した肝組織の所見は，既に著者らがラットやマウス を in situで潅流した場合の所見,3)之ほぼ同様であっ た.すなわち, detergent 含有液で60分間潅流しても核 や細胞境界部は㓜論のこと, 毛細胆管や類洞も容易に

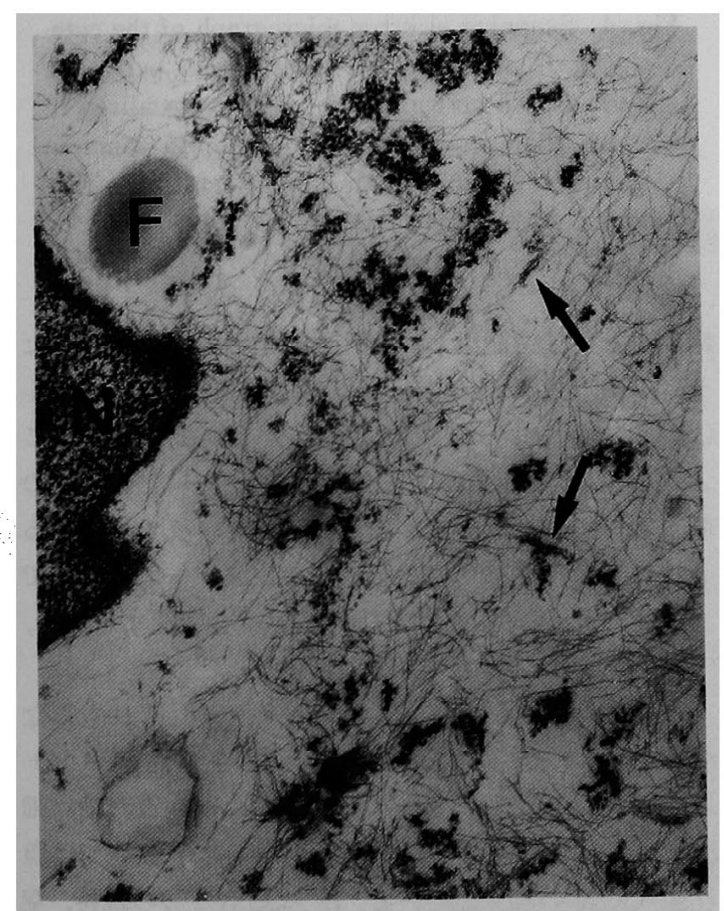

Fig. 1 Electron micrograph of hepatocyte after 60 min perfusion with Triton X-100. Numerous intermediate filaments and a few microtubules (arrows) are noted in the cytoplasm. Many intermediate filaments attach to nucleus $(\mathrm{N})$ and fat droplet (F). $\times 26,000$
同定でき，肝細胞索も比較的良好に保たれていた(Fig. 2). 細胞質には H-CS 構成するフィラメント様構造 物が比較的均一に多数存在していた。脂肪滴の存在し ていた部位は半球状に堀れ込み，その周囲をつィラメ ントが取り囲むように存在していた。強拡大で核周团 のフィラィントを観察すると, ラットやマウスでみら れたと同様に, 直径 $20 \mathrm{~nm}$ 前後の IFs と想定されるCS の多くは核の表面でループを形成し，核の表面に付着 していた（Fig. 3）。細胞質内には20nm 前後の直径を 示す CS が多数存在し，多くは相互に接着し，立体的網 目状構造を形成していた。グリコーゲン顆粒やリボ ゾームと思われる顆粒状物質が散在し，それらはフィ ラメントに付着していた（Fig. 4). 直径 $30 〜 35 \mathrm{~nm} の$ フィラィントも存在し、これらの一部は微小管と考学 られた。毛細胆管周囲を観察すると，管腔の周囲には 顆粒状構造物とともに大小種々のフィラメントが存在 し，これらは細胞膜の成分の一部やマイクロフィラメ ントとIFsで構成されているものと想定された（Fig.

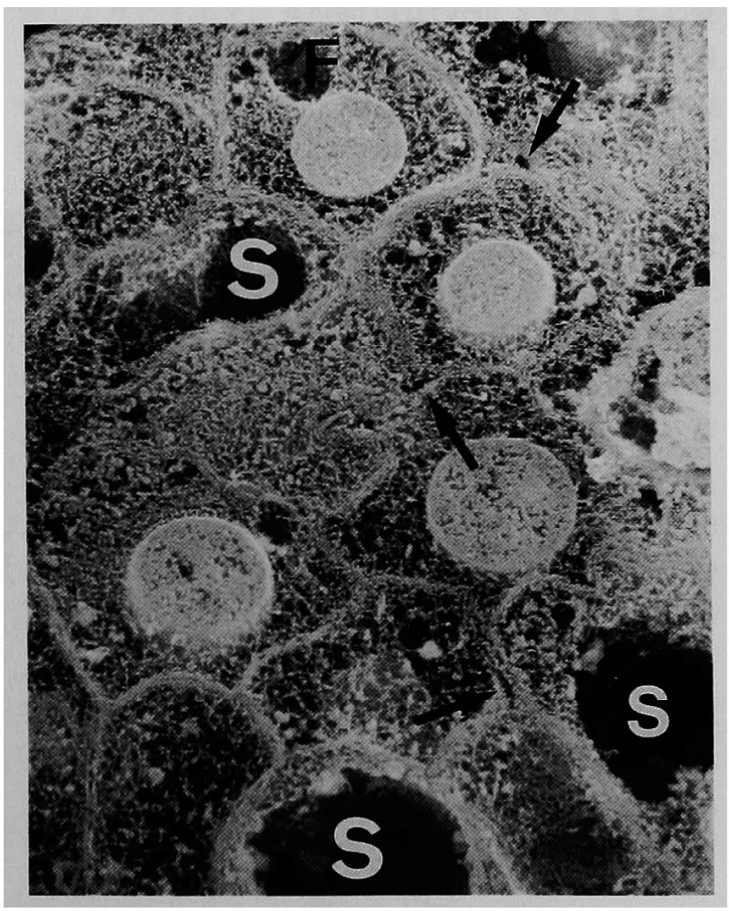

Fig. 2 Scanning electron micrograph of liver tissue after $60 \mathrm{~min}$ perfusion with Triton X-100. Hepatocytes with round-shaped nuclei are clearly demonstrated, and they are normally arranged. Sinusoidal spaces (S), fat droplet (F) and bile canaliculi (arrows) are noted. $\times 1,800$ 


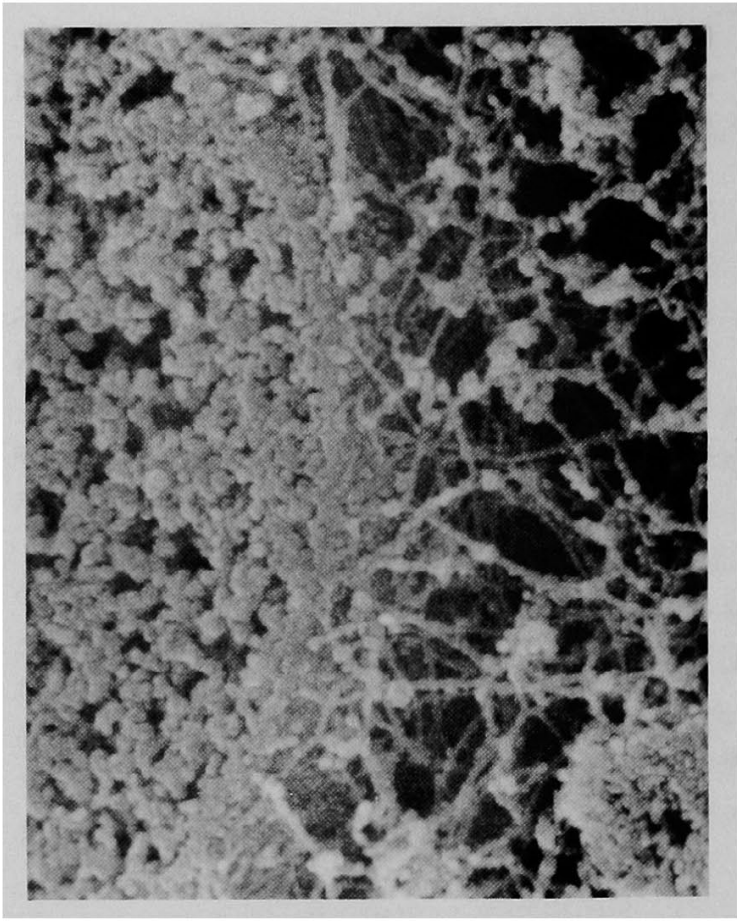

Fig. 3 Scanning electron micrograph of hepatocyte after $60 \mathrm{~min}$ perfusion with Triton $\mathrm{X}$. 100. The filaments make loop and attach to the nuclear surface. $\times 13,000$

5).

第 2 法により処理した肝組織では，しばしば肝細胞 と肝細胞の間で割断され，第 1 法では観察しえなかっ たような所見が得られた。すなわち，弱拡大で観察す ると縦に割断された毛細胆管が捉えられ，きわめて密 集したフィラメントがビマン性に存在していた（Fig 6). 細胞境界部や毛細胆管周团を拡大して観察すると, 顆粒状搆造物の集簇した部には直径 $15 ２ 2 \mathrm{~nm}$ のフィ ラメントが多数付着あるいは侵入している像が観察で きた(Fig. 7)。この顆粒状構造物はその存在部位から， 残存した細胞膜の一部とフィラメントの断面で構成さ れたものと同定した。細胞質のフィラメントは高頻度 に相互に接着・吻合し，きわめて密な網状構造を形成 していた。

\section{考 案}

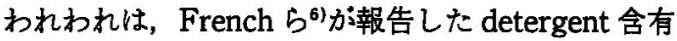
液で in situ の肝潅流を行い透過電顕で H-CSを観察 する方法を走査䉓顕に応用し，ラットやマウスの H. CS ま三次元的に表示し報告してきた。

今回，ヒ卜揳状肝生検組織を用いて透過電顕，走查

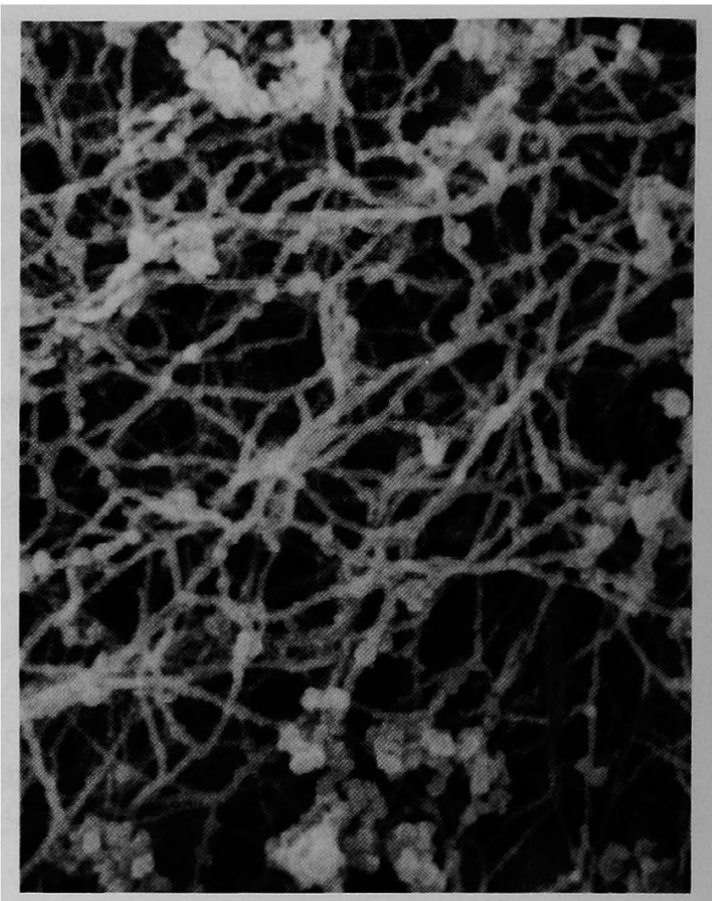

Fig. 4 Scanning electron micrograph of the cytoplasm of a hepatocyte after $60 \mathrm{~min}$ perfusion. Filamentous networks are clearly visualized in which filaments range from $15 \mathrm{~nm}$ to $35 \mathrm{~nm}$ in diameter. Granular materials attach to the filaments. $\times 18,000$

電顕で H-CS を観察し，in situの潅流により処理した ラットやマウスの H-CS と㕆ば同様に，七ト肝の H$\operatorname{CS}$ の二次元的, 三次元的存在様式を明瞭に捉えるこ とが出来た．とくに，第 2 法で試みた, $1 \times 1 \times 5 \mathrm{~mm}$ の 肝組織片を冷却割断の後 detergent 含有液で処理する 方法は，針生検でえた肝組織片の観察にも応用可能で あり,今後七トの肝細胞細胞骨格病理を研究する上飞, この研究方法は有用であると考皇た。

H-CS には 3 種の構成成分があり，それぞれ多彩な 機能を有している，すなわち，マイクロフィラメント は細胞外形の形成, 細胞の収縮運動, 細胞質流動, 細 胞接着の補強などの機能を有し，とくに肝細胞では胆 汁生成に深く関与している. IF は細胞外形の維持, 空 間的統合，細胞接着 (desmosome) の補強など，いわ ゆる骨格としての基本構筑にきわめて重要な CS であ る。微小管は細胞内の物質移送に大きな役割を果たし て拉り，細胞膜の機能調節，細胞の外形形成や細胞分 裂に必須のCS である. しかし，これら 3 種の CS は相 


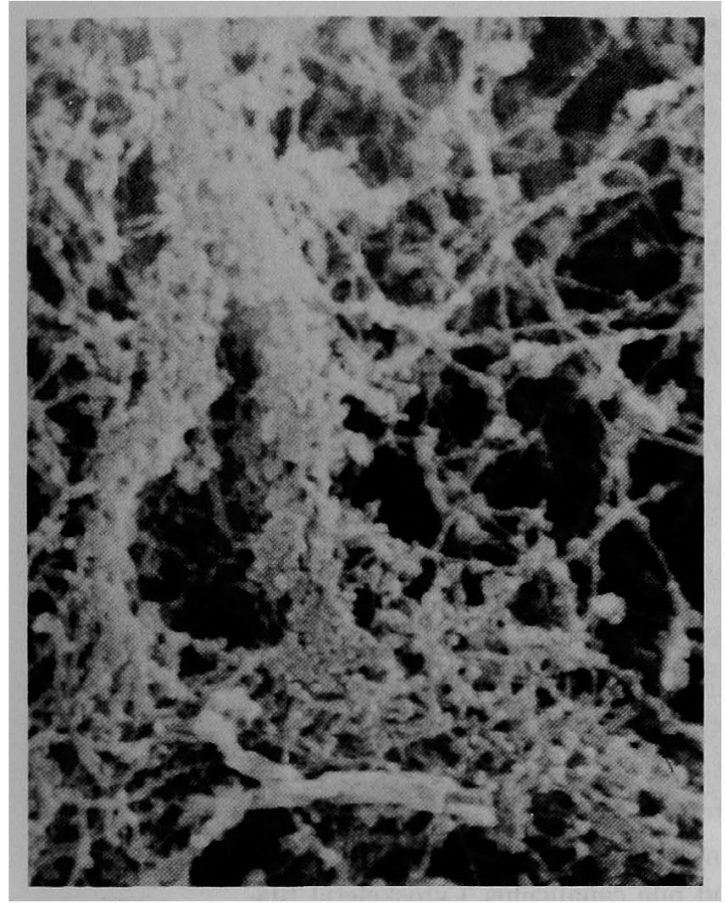

Fig. 5 Scanning electron micrograph of the bile canaliculus of hepatocyte after 60 min perfusion. Dense filamentous structures are noted around bile canaliculus and at the cell borders. $\times 18,000$
互に密接な関連性を有して存在し，その機能の発現に む互いに関与している。

マイクロフィラメントはアクチンをその構成蛋白と し，アクチンーミオシン系の作働により胆汁が生成さ れる。薬剤性肝障害などに出現する肝内胆汁うっ滞は アクチンーミオシン系の機能障害によるすのと想定さ れている ${ }^{7,8)}$ 、マイクロフィラメントは膜の裏打ち構造 としても重要な CSであり，多くは毛細胆管周囲と細 胞膜に接着して存在していると考えられている.0.5\% Triton X-100を含む液で処理することにより膜が障害 されるため, マイクロフィラメントがどの程度，また どのような形態で残存しているのか定かではない.し かし，第 2 法では潅流法とは異り毛細胆管周囲や原形 質膜が比較的良好に保たれており，この部位にきわめ て多数のフィラメントが残存していることから，種々 の病態時のマイクロフィラメントの変化を観察する上 に有用な方法である．微小管は detergent 処理の時間 が長くなるにつれて徐々に流失，減少してゆくものと 考えられる. 従って走査電顕て H-CS をより明瞭に観 察しょうとすると，長時間 detergent を使用する必要 があり，钽小管はかなり減少する。一方，IFsはそれ自 体は動的意味を持たず，生化学的にも形態学的・機能 的にもきわめて安定した CS と言われている. IF は高

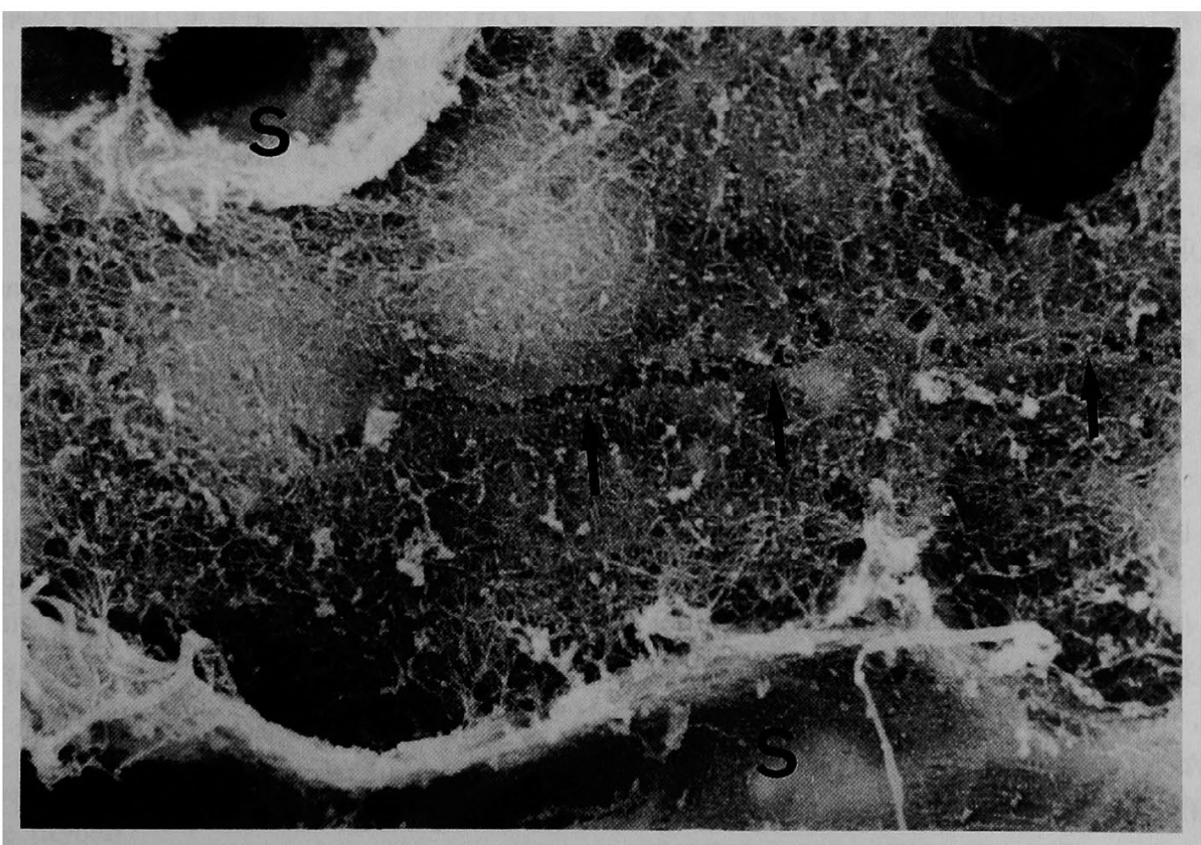

Fig. 6 Scanning electron micrograph of hepatocytes longitudinally cracked by razor blade and immersed in detergent solution. Sinusoidal spaces (S) and bile canaliculus (arrows) are clearly seen. $\times 2,500$ 


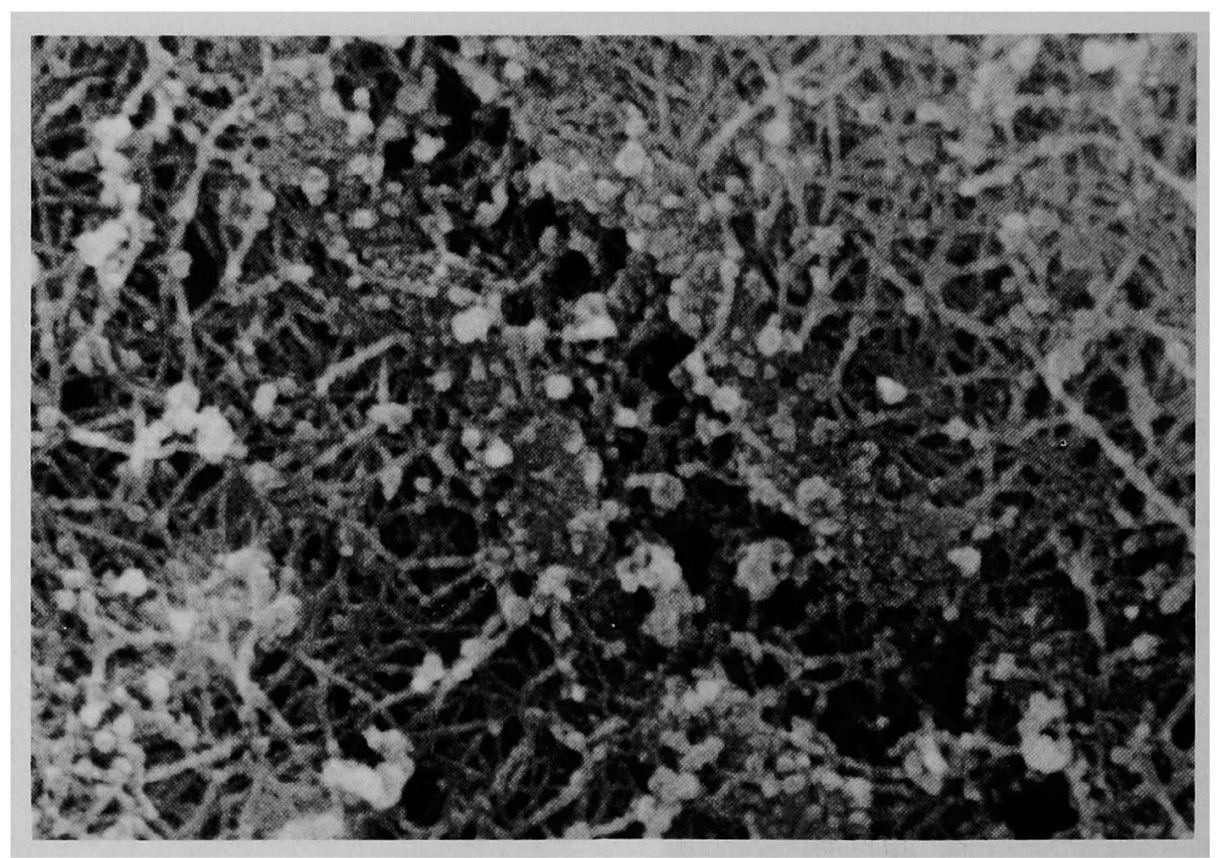

Fig. 7 Higher magnification of Fig. 6. Innumerable cytoskeletal filaments are noted in the cytoplasm, especially around bile canaliculus. Cytoskeletal filaments show mutual many contacts. $\times 26.000$

頻度に相互に接着・吻合を示し，細胞質内では安定し た状態で存在し, detergent 処理にも強い抵抗性を有 している. 従って，著者らの観察法でIFs の定量的解 析が可能である.

H-CSの観察法には，著者らの方法以外にも多くの 報告がある. Triton X-100以外の界面活性剂9やサポ ニン10)を使用する方法る報告されているが，これらの 方法ではCS の定量的解析は困難である. 三次元的な 存在様式の観察として，急速凍結ディープエッチング レプリカ法も試みられている(1)が，現時点では微細な 解析は困難である。

IFs はアルコール性肝炎などに出現するマロリー体 (Mallory body) の形成に直接関与していることを Denk $5^{12)}$, French $ら^{13)}$ ，著者ら ${ }^{14-16)}$ が明らかにして いる. またわれわれは実験的肝内胆汁らっ滞 ${ }^{17) や ラ ッ ~}$ トの閉塞性黄疾 ${ }^{18)}$ 時にも IF は変化することを明らか にして招り，IFは従来考えられていた程に安定・不变 のCSではないるのと思われる。

走査電顕は 3 種の H-CS の相互関係を研究するのに 有力な手段である. 病的状態は勿論のこと，正常状態 に颃いても 3 種の H-CS の存在様式や機能の発現に際 しての相互関係に関しては未だ不明な点が多い.今後,
試料作成法の改良や免疫電顕による検討を行い,これ らの点を明らかにし，肝疾患の細胞骨格病理をより明 確にしてゆく所存である。

本研究の一部は文部省科学研究費59570309によった. 文献

1) Okanoue $T$, Kondo I, Ihrig $T J$, et al : Effect of ethanol and chlorpromazine on transhepatic transport and biliary secretion of horseradish peroxidase. Hepatology 4 : 253-260, 1984

2) Okanoue $T$, Ohta $\mathrm{M}, \mathrm{Ou} \mathrm{O}$, et al: Scanning electron microscopy of liver cell cytoskeleton. Hepatology 5 : 1-6, 1985

3）太田正治, 岡上 武, 王 醖玉, 他：マウス肝紐胞 サイトスケルトンの立体構築ーラットとの比較を 含めて. 肝缄 $26: 598-604,1985$

4) Fey EG, Penman S: New views of cell and tissue cytoarchitecture: Embedment-free electron microscopy and biochemical analysis. Hepatology 5 : 152-158, 1985

5) Jahn $W$ : The cytoskeleton of rat liver parenchymal cells. Naturwissenschaften $67: 568,1980$

6) French SW, Kondo I, Irie $T$, et al: Mor- 
phologic study of intermediate filaments in rat hepatocytes. Hepatology $2: 29-38,1982$

7) Phillips MJ, Oda M, Mak E, et al: Microfilament dysfunction as a possible cause of intrahepatic cholestasis. Gastroenterology 69: 48 $-58,1975$

8) Phillips MJ, Oshio C, Miyairi M, et al : Intrahepatic cholestasis as a canalicular motility disorder: Evidence using cytochalasin. Lab Invest $48: 205-211,1983$

9) Fiskum G, Craig SW, Decker GL, et al: The cytoskeleton of digitonin-treated rat hepatocyte. Proc Natl Acad Sci USA 77 : 3430-3434, 1980

10）石井元康, 小林光樹, 宮崎 豊, 他：上卜肝細胞細 胞骨格観察法の改良、肝歲 $27: 110,1986$ (第22 回日本肝葴学会総会講演要旨)

11）宜保行雄, 中村 信, 古田清, 他: 急速凍結 ディープェッチングレプリカ法によるヒト生検組 織の砫細構造に関する検討. 肝葴 $27: 523-524$, 1986

12) Denk H, Franke WW, Dragosics B, et al: Pathology of cytoskeleton of liver cells : Demonstration of Mallory bodies (alcoholic hyalin) in murine and human hepatocytyes by immunofluorescence microscopy using antibodies to cytokeratin polypeptides from hepatocytes. Hepatology $1: 9-21,1981$

13) French SW: The Mallory body: Structure, composition, and pathogenesis. Hepatology 1 : $76-83,1981$

14) Okanoue $\mathrm{T}$, Ohta $\mathrm{M}, \mathrm{Ou} \mathrm{O}$, et al : Relationship of Mallory bodies to intermediate filaments in hepatocytes: A scanning electron microscopy study. Lab Invest $53: 534-540,1985$

15）岡上 武, 太田正治, 瀧野辰郎：肝細胞サイトスケ ルトンーintermediate filaments. 肝胆脑 11 : $707-716,1985$

16) 岡上 武, 太田正治：アルコールと肝細胞小器官, サイトスケルトン，医学のあゆみ $136: 1133$ $-1138,1986$

17）太田正治：肝細胞サイトスケルトンからみた肝内 胆汁らっ滞の病態一免疫䈏光法, 透過電䫒および 走查電顕による研究. 京府医大誌 $95: 571-584$, 1986

18）岡上 武, 太田正治, 加知一友, 他：ラット閉塞性 黄疸の肝細胞サイトスケルトンに関する研究. 肝 臓 $26: 669,1985$

\title{
Transmission and scanning electron microscopy of the human liver cell cytoskeleton
}

\author{
Takeshi OKanoue, Masaharu OHTA, Kazutomo KachI, Hisaichi YaMagishI, \\ Takeshi HIRONAKa, Hikoharu KaNAOKA, Yoshihiko SAWA, Yoshiharu OHTA, \\ Ongyoku OU, Keizo KagaWA, Tadao OKUno and Tatsuro TaKino
}

Human liver tissues were cracked in isopentane cooled by liquid nitrogen followed by immersion in $0.5 \%$ Triton $\mathrm{X}-100$ or were perfused with $0.5 \%$ Triton $\mathrm{X}-100$ and then fixed. Liver tissues were investigated by transmission and scanning electron microscope. Numerous intermediate filaments, a few microtubules and many microfilaments were noted in the cytoplasm of hepatocyte in situ. Three dimensional filamentous networks were visualized which were more prominent around bile canaliculi and at cell borders. Many microfilaments were preserved in the materials which were cracked in the isopentane at first. These results indicate that these methods are very useful to investigate cytoskeletal pathology of liver diseases.

Third Department of Internal Medicine and Second Department of Surgery, Kyoto Prefectural University of Medicine (Kyoto) 